\title{
Use of conditioners in the production of Tifton 85 grass hay
}

\author{
Deise Dalazen Castagnara ${ }^{1}$, João Paulo Ames ${ }^{1}$, Marcela Abbado Neres ${ }^{1}$, Paulo Sérgio \\ Rabello de Oliveira ${ }^{1}$, Francieli Batista Silva ${ }^{1}$, Eduardo Eustáquio Mesquita ${ }^{1}$, José Renato \\ Stangarlin ${ }^{1}$, Gilmar Franzener ${ }^{1}$
}

\footnotetext{
${ }^{1}$ Universidade Estadual do Oeste do Paraná - Centro de Ciências Agrárias - CCA, Campus de Marechal Cândido Rondon. Rua Pernambuco,1777, Caixa Postal 91, Marechal Cândido Rondon - PR, 85960-000.
}

ABSTRACT - The objectives of this study were to estimate the curve of dehydration, bromatological composition and occurrence of fungi in Tifton 85 grass, submitted to four methods of dehydration. The curves of dehydration were studied in a completely randomized design with a $4 \times 11$ factorial scheme with four drying systems ( 1 conditioning +1 turn-over; 2 conditionings +1 turn-over; no conditioning +1 turn-over and no conditioning +2 turn-overs) and 11 sampling times $(0,3,15,18,21,24,39,42,45$ and 47 hours after the cutting), with six replicates. For the bromatological composition and fungi occurrence, the experimental design was completely randomized in a $4 \times 3$ factorial scheme with the four drying methods of Tifton 85 grass and three periods of evaluation (before the cutting, at the time of the baling and 30 days after storage) with six replicates. It was found that after the first hour after cutting and at the end of the period of dehydration, Tifton 85 plants that were treated with conditioners showed higher levels of dry matter. Stored hay that was treated with conditioners presented higher levels of acid detergent insoluble protein. Until baling, the drying methods did not alter the crude protein content of hay; however, after storage, the hay submitted only to turn-over showed crude protein content higher (13.90\%) than those submitted to conditioners $(9.94 \%)$. There was an increase in the occurrence of fungi after storage, but the application of conditioners and one turn-over resulted in lower CUF/g, compared with other treatments, enhancing the effect of conditioners on accelerating the dehydration rate and obtaining better hay storage conditions.

Key Words: conservation, crude protein, dehydration, storage fungus

\section{Introduction}

Conserved forages such as hay and silage can have their food value changed greatly because of the procedures adopted for their production and preservation, as well as chemical and microbiological phenomena that occur in the process (Jobim et al., 2007). For Reis et al. (2001), in addition to age and species of forage plants, the main factors that influence the obtention of a high quality hay is cutting management, which aims at rapid dehydration, and expertise to overcome the obstacles presented by environmental factors. These factors directly interfere with the chemical and sanitary quality of hay, as well as losses in production (Domingues, 2009). Muck \& Shinners (2001) indicate the need for research to understand the processes that affect the quality of hay during production and storage and develop practical ways to reduce losses and improve quality. According to Rotz (1995), the majority of losses occurrs in the first 30 days of storage. The fungi population undergoes accented changes with decrease of those genera typical of the field, such as Fusarium and Cladosporium and increase of Aspergillus and Penicillium during storage (Hlodversson \& Kaspersson, 1986).

Mower conditioners are widely used for plant dehydration and hay production, and their acquisition by producers has been growing every year, in order to reduce the risk of losses from rainfall through the acceleration of the dehydration process. The conditioners have emerged in the 40's with the aim of aiding at plant dehydration by crushing the stems. There are conditioners on the market today with free swinging flail fingers and rollers. This acceleration causes a beneficial effect in the final stage of dehydration, when the removal of moisture is slower because it happens through the cuticle (Moser, 1995). However, the mechanical injuries on the plant can cause changes in bromatological composition and digestibility of forage, making it necessary to evaluate its effects on the final composition of the hay produced.

In this sense, this experiment aimed to assess the rates of dehydration, bromatological composition and occurrence of fungi in Tifton 85 hay produced under different methods of dehydration. 


\section{Material and Methods}

The experiment was conducted under field conditions at the Fazenda Experimental Antônio Carlos dos Santos Pessoa, in the Universidade Estadual do Oeste do Paraná, campus of Marechal Cândido Rondon, having as coordinates latitude $24^{\circ} 33^{\prime}$ 40" S, longitude $54^{\circ} 04^{\prime} 12$ " W and altitude of $420 \mathrm{~m}$. The local climate, classified according to Koppen Cfa, is subtropical with rainfall well distributed during the year and hot summers. The average temperatures of the coldest quarter vary from 17 to $18^{\circ} \mathrm{C}$, while the warmest ones vary from 28 to $29^{\circ} \mathrm{C}$ and annual average temperature varies from 22 to $23^{\circ} \mathrm{C}$. The total average annual rainfall for the region ranges from 1,600 to $1,800 \mathrm{~mm}$, with the wettest quarter showing totals ranging from 400 to $500 \mathrm{~mm}$ (IAPAR, 2006). During growth and drying of plants, climatic conditions were favorable (Figure 1; Table 1).

The experimental area is classified as Oxisol (EMBRAPA, 2006) and has the following chemical characteristics: $\mathrm{pH}$ in water-5,70; $\mathrm{P}$ (Mehlich) $-10.78 \mathrm{mg} / \mathrm{dm}^{3}$; $\mathrm{K}$ (Mehlich) - 0, $13 \mathrm{cmol}_{\mathrm{c}} / \mathrm{dm}^{3} ; \mathrm{Ca}^{2+}(\mathrm{KCl} \mathrm{mol} / \mathrm{L} 1 \mathrm{1})$ $5.21 \mathrm{cmol}_{\mathrm{c}} / \mathrm{dm}^{3} ; \mathrm{Mg}^{2+}(\mathrm{KCl} 1 \mathrm{~mol} / \mathrm{L})-0.91 \mathrm{cmol}_{\mathrm{C}} / \mathrm{dm}^{3} ; \mathrm{Al}^{3+}$ $(\mathrm{KCl} 1 \mathrm{~mol} / \mathrm{L})-0.00 \mathrm{cmol}_{\mathrm{c}} / \mathrm{dm}^{3} ; \mathrm{H}+\mathrm{Al}$ (calcium acetate $0.5 \mathrm{~mol} / \mathrm{L})-4.14 \mathrm{cmol}_{\mathrm{c}} / \mathrm{dm}^{3}$; SB - $6.15 \mathrm{cmol}_{\mathrm{c}} / \mathrm{dm}^{3}$; CTC $10.29 \mathrm{cmol}_{\mathrm{c}} / \mathrm{dm}^{3} ; \mathrm{V}-59.77 \%$; organic matter (Boyocus Method) - $30.07 \mathrm{~g} / \mathrm{dm}^{3}$ and clay - $65 \%$.

The experiment was installed in a field of hay production in 2004 implanted with Cynodon sp. cv. Tifton 85, and has an area of 1.3 hectares, managed exclusively for hay production. At the moment of cutting, Tifton 85 showed regrowth age of 42 days and plants had an average height of $35 \mathrm{~cm}$.

The cut of the experimental area was performed at 2 p.m. on 3/29/2010, with the help of a rotary mower and at

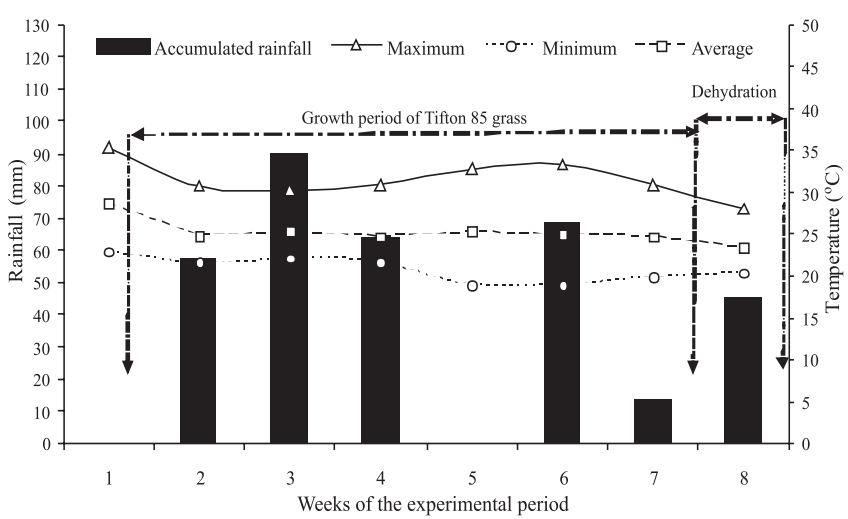

Figure 1 - Climatic data of the experiment (Marechal Cândido Rondon, February-March of 2010).
Table 1 - Climatic data on the dates for the cutting and drying of the Tifton 85 plants (Marechal Cândido Rondon, March of 2010)

\begin{tabular}{|c|c|c|c|}
\hline \multirow[t]{2}{*}{ Date } & \multicolumn{3}{|c|}{ Temperature $\left({ }^{\circ} \mathrm{C}\right)$} \\
\hline & Average & Maximum & Minimum \\
\hline $3 / 29 / 2010$ & 23.7 & 30.4 & 19,5 \\
\hline $3 / 30 / 2010$ & 25.0 & 31.7 & 20,1 \\
\hline \multirow[t]{2}{*}{$3 / 31 / 2010$} & 24.7 & 30.6 & 19,8 \\
\hline & \multicolumn{3}{|c|}{ Relative air humidity (\%) } \\
\hline $3 / 29 / 2010$ & 80.5 & 97.0 & 48,0 \\
\hline $3 / 30 / 2010$ & 74.5 & 96.0 & 43,0 \\
\hline \multirow[t]{2}{*}{$3 / 30 / 2010$} & 78.6 & 94.0 & 53,0 \\
\hline & \multicolumn{3}{|c|}{ Dewpoint $\left({ }^{\circ} \mathrm{C}\right)$} \\
\hline $3 / 29 / 2010$ & 21.8 & 18.8 & 19,3 \\
\hline $3 / 30 / 2010$ & 20.7 & 19.4 & 18,9 \\
\hline \multirow[t]{2}{*}{$3 / 31 / 2010$} & 22.7 & 19.1 & 19,9 \\
\hline & Radiation $\left(\mathrm{KJ} / \mathrm{m}^{2}\right)$ & \multicolumn{2}{|c|}{ Rainfall (mm) } \\
\hline $3 / 29 / 2010$ & 19851.452 & \multicolumn{2}{|c|}{0.0} \\
\hline $3 / 30 / 2010$ & 21873.094 & \multicolumn{2}{|c|}{0.0} \\
\hline $3 / 31 / 2010$ & 17384.410 & \multicolumn{2}{|c|}{0.0} \\
\hline
\end{tabular}

$10 \mathrm{~cm}$ from the soil. Conditioning was done two hours after cutting with the aid of tractor conditioner with free swinging flail fingers, while the turning over was performed at 5 p.m. and 11 p.m., after cutting, with the aid of a tractor rake.

For determination of the drying curves, a completely randomized design in a $4 \times 10$ factorial scheme, composed of four methods for the dehydration of hay: 1 passage of conditioner +1 turn-over ( 1 cond. +1 turn-over); 2 passages of conditioner +1 turn-over ( 2 cond. +1 turn-over); no conditioner +1 turn-over ( 1 turn-over) and no conditioner +2 turn-overs ( 2 turn-overs) and 10 sampling times ( $0,3,15$, $18,21,24,39$, 42, 45 and 47 hours after harvest), with six replicates. Collection times corresponded to the following times: $1^{\text {st }}$ day (cut day): time $0=2$ p.m., time $3=5$ p.m.; $2^{\text {nd }}$ day: time $15=8$ a.m., time $18=11$ a.m., time $21=2$ p.m., time $24=5$ p.m.; $3^{\text {rd }}$ day: time $39=8$ a.m., time $42=11$ a.m., time $45=2$ p.m., and time $47=4$ p.m.

The production of dry matter (DM) and leaf:stem relation were studied according to a randomized design with four treatments and six replications. For the bromatological composition and occurrence of fungi, the experimental design was completely randomized in a $4 \times 3$ factorial scheme with four methods for the dehydration of hay and three sampling periods (before the cut, at the time of baling and 30 days after storage) with six replicates.

The sampling for the determination of MS production was performed before the mower passing with a square of $1 \mathrm{~m}^{2}$ randomly placed in each plot. Samples were separated into two sub samplings, from which the first one was destined to the evaluation of the bromatological composition and the second one was separated into leaves (leaf lamina) 
and stems (culms + sheaths). All samples were separated and packed in paper bags, weighed and placed in an oven with ventilation force and maintained at a temperature of $55{ }^{\circ} \mathrm{C}$ for 72 hours for drying. The leaf:stem relation was calculated using the ratio of dry weight of leaves and dry weight of stems.

For the determination of the drying curves, samples of $300 \mathrm{~g}$ from each plot were collected (according to the established times), selected and dried separately using the same methodology applied to other samples. After 47 hours of dehydration at the time of baling, new sampling was performed to determine the bromatological composition. After sampling the material was baled mechanically, in rectangular bundles with an average weight of $12 \mathrm{~kg}$, stored in identical conditions of temperature, light and humidity in the shed, protected from rain and insolation. Storage time consisted of a period of 30 days, then the bundles were opened and a new sampling was conducted to determine the bromatological composition and occurrence of fungi. After drying, samples for evaluation of bromatological composition were ground in a Willey mill, with 30-mesh sieve, and stored in plastic bags, properly identified, to assess the levels of crude protein (CP) according to AOAC (1990), neutral detergent fiber (NDF), acid detergent fiber (ADF) according to Van Soest et al. (1991), neutral detergent insoluble protein (NDIP - expressed as\% of CP), acid detergent insoluble protein (ADIP expressed as \% of CP), lignin, hemicellulose and cellulose (Silva \& Queiroz, 2006).

Fungi were isolated by inducing growth of mycelium on PDA culture medium (200 g potato, $20 \mathrm{~g}$ dextrose, $15 \mathrm{~g}$ agar and 1,000 $\mathrm{mL}$ of distilled water), by induced sporulation or direct isolation of signals (reproductive structures) of the pathogen from the samples collected (Fernandez, 1993; Mehta \& Silva-Hanlin, 1997). From the observation using a stereoscopic microscope (magnifying glass), semi-permanent slides of all fungal structures found in both symptomatic and in middle of the cultivation were prepared. These structures were transferred, using a needle or dagger for the microscope slides with lactophenol cotton blue stain, covered with glass coverslips, sealed with varnish and observed on an optical microscope for fungi identification, with the help of specific identification keys (Barnett \& Hunter , 1987, Carmichael et al. 1980; Samson et al. 1995; Guarro et al., 1999).

The data reffering to the MS content of Tifton 85 over the dehydration times were subjected to regression analysis to obtain the curves of dehydration. Data from bromatological composition were submitted to statistical analysis through the SAEG software (1997), and averages were compared by using the Tukey test at 5\% of probability.

\section{Results and Discussion}

There was no statistical difference between treatments for DM yield and leaf:stem relation $(\mathrm{p}<0.05)$ (Table 2$)$. These results confirm the uniformity of the field of Tifton 85 and validate the design used for the experiment (completely randomized). The average production of MS in Tifton 85 was 4,370.63 kg/ha. Alvim et al. (1999) concluded that Tifton 85 grass can be used in cut intervals of four to six weeks, from October to March in Coronel Pacheco - MG, because besides the high DM yield, CP concentration remains high. Rocha et al. (2000) obtained average yields of 2,630 kg/ha when studying three cuts of Tifton 85 with application of $100 \mathrm{~kg} / \mathrm{ha}$ of nitrogen. As for the components of forage produced, the leaf/stem ratio was 0.95 , with an average participation of leaves at $48.60 \%$, and stems at 50.40\%. Moreira \& Reis (2007) obtained stem ratio of 0.94 in areas of Tifton 85 , values very close to those obtained in this research.

The plant dehydration in the field for prolonged periods can lead to loss of nonstructural carbohydrates due to excessive breathing and loss of leaves. According to Collins (1995), hay with drying periods exceeding seven days is not approppiate for animal consumption. After the cut (Figure 2), the plants started to dehydrate and the results fit the polynomial regression model of degree 4 . After three hours of dehydration, there were differences between the drying methods, with a faster rate of dehydration in the plots where Tifton 85 received the treatment with conditioner. However, in the beginning of each morning, the DM levels among the drying methods were very close, with an increase of moisture, which is due to the accumulated dew at night. According to Rotz (1995) rehydration of the plants with dew occurs when it is absorbed by the internal tissues, and the rate of distribution within the plants is related to cuticle

Table 2 - Dry matter production (DMP), leaf:stem relation (L:S) and proportions (\%) of leaves and stems of Tifton 85 subjected to dehydration

\begin{tabular}{lclll}
\hline Drying method & DMP & L:S & $\%$ Leaves & $\%$ Stems \\
\hline 1 cond. +1 turn-over & $3,912.47^{\mathrm{ns}}$ & $0.92^{\mathrm{ns}}$ & $47.99^{\mathrm{ns}}$ & $52.01^{\mathrm{ns}}$ \\
2 cond. +1 turn-over & $4,164.27$ & 0.98 & 49.55 & 50.45 \\
1 turn-over & $4,263.17$ & 0.98 & 49.10 & 50.90 \\
2 turn-overs & $4,142.61$ & 0.92 & 47.80 & 52.20 \\
CV (\%) & 10.10 & 12.61 & 7.00 & 6.62 \\
\hline
\end{tabular}

ns Not significant by Tukey test at $5 \%$ probability. 
thickness, leaf:stem relation, stem thickness and the use of conditioners. Results allow to infer that the use of conditioners or the more intense management with rake can promote rehydration of Tifton 85, because from time 3 (17 p.m. of the first day of dehydration) for time 15 (8 a.m. of the $2^{\text {nd }}$ day of dehydration), bigger decrease in DM was observed in the materials that underwent conditioning and two turn-overs compared with the material that underwent only one turn-over (Table 3). Likewise, time 24 (17 p.m. of the $2^{\text {nd }}$ day of dehydration) for time 39 ( 8 a.m. of the $3^{\text {rd }}$ day of dehydration), the conditioned material decreased more sharply in the DM content compared with the materials submitted only to turn-overs (Table 3 ).

After the drying of the dew, at the second collection of the $2^{\text {nd }}$ day of dehydration (18 hours after the cutting), the hay derived from the conditioned forages once more showed higher DM contents; however at the end of the drying period (45 and $47 \mathrm{~h}$ after cut) the DM contents became closer (Table 3 ). At the time of baling ( $47 \mathrm{~h}$ after cutting), only the material submitted to two conditionings showed DM contents above $80 \%$, recommended for the hay storage (Pupo, 1995). The differences in the DM contents at the moment of baling can lead to differences in the quality of the hay stored, causing increases in the respiration rate and favoring the occurrence of fungi and loss of nutritional quality of the hay stored with lower levels of DM. Even in

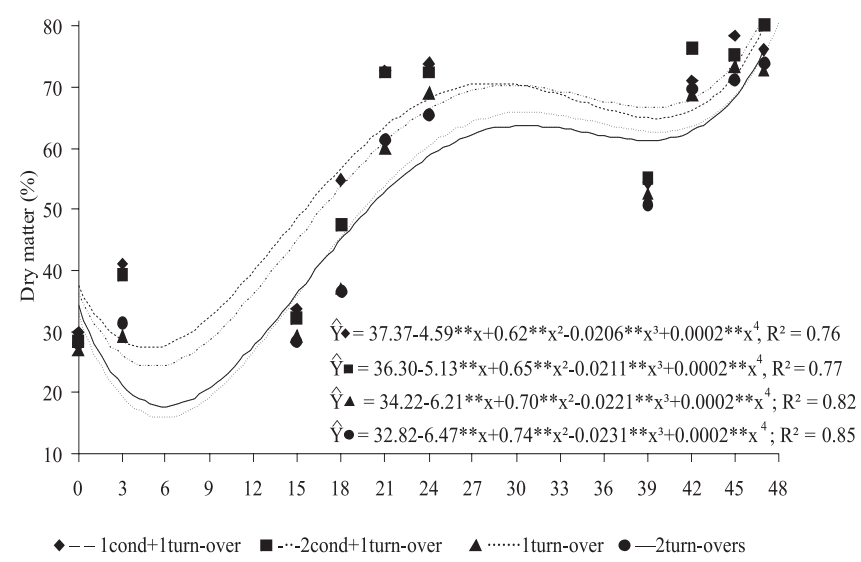

Figure 2 - Effect of drying methods on contents of dry matter in hay at dehydration times. the stored hay there are losses, mainly due to fermentation and the action of humidity. The losses occur because the starch and sugars of the forage are transformed into water and carbon dioxide gas through fermentation processes. However, these losses can be reduced if the hay is stored with appropriate content of DM and protected from humidity and rain, because those care impede or attenuate the fermentation and the temperature rise.

The use of conditioners as accelerator of the dehydration rate should be evaluated not only for accelerating the rate of dehydration, but also for the nutritional quality of the hay produced, since the injuries caused by the implementation in plants may affect their bromatological composition. However, it is known that the most severe effects occur with the use of conditioners on the plants under conditions of high humidity or rainfall during the period of dehydration, which was not observed in the experiment.

At the moment of the cutting, Tifton 85 grass had similar values of NDF on different methods of drying, with an average of $86.00 \%$ (Table 4 ). These values are high and may affect the intake and digestibility by animals, but results from other research studies show that the species of Cynodon presents high concentration of NDF even when harvested in the vegetative stage (Oliveira et al., 2000; Ribeiro et al ., 2001; Reis et al., 2003). The fiber content is used as a negative index of diet quality, as it represents the least digestible fraction of the food. However, fiber is required for normal metabolism and functioning of the rumen, so the fiber quality is an important factor in the diet of ruminants, particularly in lactating dairy cows (Matos, 1989).

After storage, NDF values were on average $80.62 \%$ with a higher content in the hay with passages of conditioner $(p<0.05)$. Scheffer-Basso et al. (2008) obtained NDF values of $73.6 \%$ for Tifton 85 fertilized with pig slurry.

The ADF values did not differ between treatments ( $>0.05)$ or between cuts, with an average of $41.25 \%$ (Table 4). Scheffer-Basso et al. (2008) obtained in Tifton 85 ADF values ranging from 43.5 to $41.5 \%$ for assessments conducted in January and February. Reis et al. (2003) obtained $41.8 \%$ of ADF for Coast-cross grass at the beginning of flowering.

Table 3 - Dry matter content of Tifton 85 under four drying methods for hay production at the different period of dehydration

\begin{tabular}{lccccccccccc}
\hline Drying methods & \multicolumn{10}{c}{ Dehydration times (h) } \\
\cline { 2 - 10 } & 0 & 3 & 15 & 18 & 21 & 24 & 39 & 42 & 45 & 47 \\
\hline 1 cond. + 1 turn-over & $30.00 \mathrm{a}$ & $41.16 \mathrm{a}$ & $33.83 \mathrm{a}$ & $55.00 \mathrm{a}$ & $72.66 \mathrm{a}$ & $73.83 \mathrm{a}$ & $54.33 \mathrm{a}$ & $71.16 \mathrm{~b}$ & $78.50 \mathrm{a}$ & $76.16 \mathrm{~b}$ \\
2 cond. + 1 turn-over & $28.50 \mathrm{a}$ & $39.33 \mathrm{a}$ & $32.16 \mathrm{ab}$ & $47.50 \mathrm{~b}$ & $72.50 \mathrm{a}$ & $72.50 \mathrm{a}$ & $55.16 \mathrm{a}$ & $76.33 \mathrm{a}$ & $75.33 \mathrm{ab}$ & $80.33 \mathrm{a}$ \\
1 turn-over & $27.00 \mathrm{a}$ & $29.16 \mathrm{~b}$ & $29.33 \mathrm{bc}$ & $37.00 \mathrm{c}$ & $60.16 \mathrm{~b}$ & $69.00 \mathrm{~b}$ & $52.50 \mathrm{ab}$ & $68.83 \mathrm{~b}$ & $73.50 \mathrm{bc}$ & $72.66 \mathrm{c}$ \\
2 turn-overs & $28.16 \mathrm{a}$ & $31.50 \mathrm{~b}$ & $28.50 \mathrm{c}$ & $36.50 \mathrm{c}$ & $61.50 \mathrm{~b}$ & $65.66 \mathrm{~b}$ & $50.66 \mathrm{~b}$ & $69.66 \mathrm{~b}$ & $71.33 \mathrm{c}$ & $73.83 \mathrm{bc}$
\end{tabular}

Means followed by different letters in the column differ by Tukey test at $5 \%$ of probability. 
The hemicellulose levels did not differ between the drying methods at all times evaluated, but in general, a tendency of decrease with storage was observed (Table 4). The hemicellulose is a heterogeneous collection of amorphous polysaccharides with much lower degree of polymerization cellulose (Van Soest, 1994) and its digestibility varies depending on the quantities of monomers (xylose, arabinose and galacturonic acid) that form the molecule (Ladeira et al., 2002).

The values of cellulose (Table 4) were on average $56.63 \%$, and according to Van Soest (1994), the cellulose is a major constituent of the cell wall and its contents can vary from 20 to $40 \%$.

The values obtained were high, due to the age of forage regrowth (42 days), time of the year and the higher proportion of stems in relation to leaf shown at the time of cutting. The hemicellulose contents did not differ between the drying methods in the three periods evaluated, but when the comparison was made between periods, the values were lower after the storage in the material that only underwent turn-overs with rake.
Lignin is a constituent of the cell wall that has a negative influence on the degradation of tissues (Engels \& Jung, 2002; Lacerda et al., 2006). The values of lignin showed an average of $12.52 \%$, with reduction after storage. Reis et al. (2003) obtained 8.2\% lignin for Coast-cross grass.

At the time of cutting and baling, CP levels showed no significant differences ( $\mathrm{p}>0.05$ ) between drying methods (Table 4). However, after storage, the materials submitted only to turn-overs showed CP contents higher than the ones submitted to conditioning. Regarding the evaluation periods for the drying method with a conditioning, reduction in CP content after storage was observed, whereas an opposite behavior was observed in the hay produced with two turn-overs with rake (Table 4). The double turn-over tools with rake did not increase the rate of dehydration or compromised forage quality in comparison with a single turn-over, thus the recommendation of a single turn-over, when weather conditions are favorable for drying. It is important to emphasize that turning over must be done in the early hours of drying, resulting in acceleration in the rate of dehydration, which is not recommended in the final

Table 4 - Bromatological composition of Tifton 85 hay under different methods of dehydration, before the cut, at the time of baling and 30 days after storage

\begin{tabular}{|c|c|c|c|c|c|c|c|c|}
\hline \multirow[t]{2}{*}{ Drying methods } & \multicolumn{4}{|c|}{ NFD (\%) } & \multicolumn{4}{|c|}{ AFD (\%) } \\
\hline & Cut & Baling & Storage & Means & Cut & Baling & Storage & Means \\
\hline 1 cond. + 1 turn-over & $86.86 \mathrm{aA}$ & $86.11 \mathrm{aA}$ & $81.80 \mathrm{aB}$ & $84.93 a$ & $42.33 \mathrm{aA}$ & $39.87 \mathrm{aA}$ & $40.41 \mathrm{aA}$ & $40.87 \mathrm{a}$ \\
\hline 2 cond. +1 turn-over & $85.30 \mathrm{aA}$ & $85.32 \mathrm{aA}$ & $82.83 \mathrm{aA}$ & $84.48 \mathrm{ab}$ & $42.86 a \mathrm{~A}$ & $40.66 \mathrm{aA}$ & $42.06 \mathrm{aA}$ & $41.86 a$ \\
\hline 1 turn-over & $85.37 \mathrm{aA}$ & $84.07 \mathrm{aA}$ & $77.45 b B$ & $82.30 \mathrm{~b}$ & 41.99а A & $39.05 \mathrm{aA}$ & $40.82 \mathrm{aA}$ & $40.63 a$ \\
\hline 2 turn-overs & $86.45 \mathrm{aA}$ & $82.95 \mathrm{aAB}$ & $80.42 \mathrm{abB}$ & $83.28 \mathrm{ab}$ & $41.56 \mathrm{aA}$ & $40.27 \mathrm{aA}$ & $43.15 \mathrm{aA}$ & $41.66 \mathrm{a}$ \\
\hline Means & $86.00 \mathrm{~A}$ & $84.61 \mathrm{~A}$ & $80.62 \mathrm{~B}$ & 83.74 & $42.19 \mathrm{~A}$ & $39.96 \mathrm{~B}$ & $41.61 \mathrm{~A}$ & 41.25 \\
\hline \multirow[t]{2}{*}{ CV\% } & \multicolumn{4}{|c|}{3.01} & & & & \\
\hline & \multicolumn{4}{|c|}{ Hemicellulose (\%) } & \multicolumn{4}{|c|}{ Celullose (\%) } \\
\hline 1 cond. + 1 turn-over & $44.53 \mathrm{aAB}$ & $46.24 \mathrm{aA}$ & 41.39аB & $44.05 a$ & 57.84 & 57.77 & 57.63 & 57.75 \\
\hline 2 cond. +1 turn-over & $42.43 \mathrm{aA}$ & $44.67 \mathrm{aA}$ & $40.77 \mathrm{aA}$ & $42.62 \mathrm{a}$ & 58.78 & 59.56 & 54.19 & 57.51 \\
\hline 1 turn-over & $43.37 \mathrm{aA}$ & $45.01 \mathrm{aA}$ & $36.63 \mathrm{aB}$ & $41.67 \mathrm{a}$ & 54.30 & 59.28 & 52.16 & 55.25 \\
\hline 2 turn-overs & $44.89 \mathrm{aA}$ & $42.68 \mathrm{aA}$ & $37.27 a B$ & $41.61 \mathrm{a}$ & 50.72 & 59.50 & 57.84 & 56.02 \\
\hline Means & $43.81 \mathrm{~A}$ & $44.65 \mathrm{~A}$ & $39.01 \mathrm{~B}$ & 42.49 & 55.41 & 59.03 & 55.46 & 56.63 \\
\hline \multirow[t]{2}{*}{$\mathrm{CV} \%$} & \multicolumn{4}{|c|}{7.57} & & & & \\
\hline & \multicolumn{4}{|c|}{ Lignin (\%) } & \multicolumn{4}{|c|}{ CP (\%) } \\
\hline 1 cond. + 1 turn-over & $12.26 \mathrm{cB}$ & $18.37 \mathrm{aA}$ & $9.45 \mathrm{aB}$ & $13.36 \mathrm{ab}$ & $11.45 \mathrm{aA}$ & $12.44 \mathrm{aA}$ & $8.92 \mathrm{cB}$ & $10.87 \mathrm{~b}$ \\
\hline 2 cond. +1 turn-over & 14.77bcA & $12.08 \mathrm{bAB}$ & $10.20 \mathrm{aB}$ & $12.35 b$ & $12.52 \mathrm{aA}$ & 11.79aA & 10.96bcA & $11.78 \mathrm{ab}$ \\
\hline 1 turn-over & $16.84 \mathrm{bA}$ & $11.83 \mathrm{bB}$ & $9.93 \mathrm{aB}$ & $12.87 \mathrm{ab}$ & $12.78 \mathrm{aA}$ & $12.46 \mathrm{aA}$ & $13.52 \mathrm{abA}$ & $12.92 \mathrm{a}$ \\
\hline 2 turn-overs & $11.12 \mathrm{aA}$ & $11.75 \mathrm{bA}$ & $11.70 \mathrm{aA}$ & $11.52 \mathrm{a}$ & $11.90 \mathrm{aB}$ & $11.82 \mathrm{aB}$ & $14.29 \mathrm{aA}$ & $12.67 \mathrm{a}$ \\
\hline Means & $16.25 \mathrm{~A}$ & $13.51 \mathrm{~B}$ & $10.32 \mathrm{C}$ & 12.52 & $12.16 \mathrm{~A}$ & $12.12 \mathrm{~A}$ & $11.92 \mathrm{~A}$ & 12.06 \\
\hline \multirow[t]{2}{*}{$\mathrm{CV} \%$} & \multicolumn{4}{|c|}{19.13} & & & & \\
\hline & \multicolumn{4}{|c|}{$\mathrm{ADIP}^{1}(\%)$} & \multicolumn{4}{|c|}{ NDIP $^{1}(\%)$} \\
\hline 1 cond. + 1 turn-over & 38.95aA & $38.30 \mathrm{aA}$ & $47.32 \mathrm{aB}$ & $48.19 \mathrm{a}$ & $82.22 \mathrm{aA}$ & 83.99aA & $66.73 \mathrm{aB}$ & $77.65 a$ \\
\hline 2 cond. +1 turn-over & $33.17 \mathrm{aA}$ & $32.45 \mathrm{aA}$ & $45.58 \mathrm{aB}$ & $43.07 \mathrm{ab}$ & $76.04 \mathrm{aA}$ & 80.41abA & 65.86abB & $74.10 \mathrm{ab}$ \\
\hline 1 turn-over & $36.29 \mathrm{aA}$ & $32.10 \mathrm{aA}$ & 37.91bA & $38.77 b$ & $73.01 \mathrm{aA}$ & $70.73 \mathrm{bA}$ & $56.21 \mathrm{bB}$ & $66.65 c$ \\
\hline 2 turn-overs & 35.92aA & $36.45 \mathrm{aA}$ & $37.90 \mathrm{abA}$ & $43.76 \mathrm{ab}$ & $80.67 \mathrm{aA}$ & 74.64abA & 56.94abB & $70.75 b c$ \\
\hline Means & $52.34 \mathrm{~A}$ & $36.32 \mathrm{~B}$ & $41.68 \mathrm{~B}$ & 43.45 & $77.98 \mathrm{~A}$ & $77.44 \mathrm{~A}$ & $61.43 \mathrm{~B}$ & 72.28 \\
\hline $\mathrm{CV} \%$ & \multicolumn{3}{|c|}{18.50} & & \multicolumn{4}{|c|}{9.47} \\
\hline
\end{tabular}


stages of drying, when the plasma membrane has already lost its permeability and the water is more strongly retained.

The evaluation of the potential availability of nitrogen compounds of foods has received special attention in tropical conditions due to the high association with the organic matrix of the cell wall, an association that compromises the accessibility of these compounds by rumen microorganisms (Henriques et al. 2007).

ADIP was influenced by the drying methods and the evaluation periods $(\mathrm{p}<0.05)$, so that only after the storage differences were observed between the methods of drying, with worst results achieve by the method that used a single turn-over. For NDIP, there was effect of drying methods and evaluation periods $(\mathrm{p}<0.05)$. The time of baling and after storage, higher values of PIDN were observed in the hay produced with one conditioning and one turn-over in comparison with the one that underwent only one turn-over (Table 4). For all drying methods there was a reduction in the values of NDIP with storage (Table 4). These results suggest that the use of conditioners for the production of Tifton 85 hay can increase the amount of unavailable protein, impairing the nutritional value of conserved forages under this method. However, the results are still insufficient to ensure such statement, more detailed studies are needed to quantify and characterize these variables. Aguiar et al. (2006), studying tropical grass hay found values of NDIP ranging from 45.45 to 54.66\%, while Gobbi et al. (2005), in the evaluation of Brachiaria decumbens Stapf hay, found the value of $48.8 \%$ of total nitrogen linked to cell wall, and $24.8 \%$ of the nitrogen linked to the ADF.

The importance of knowing the change in the content of ADIP is because nitrogen presented in this form remains unavailable for the animal (AFRC, 1995) and is indicative of the fraction of nitrogen compounds not degradable in the rumen. However, recent studies conducted in tropical conditions showed complete absence of relationship between the fraction of non-degradable nitrogenous compounds in the rumen and ADIP, and the possibility of part of this latter being digestible in the intestine (Detmann et al., 2004). ADIP values at the time of cutting and baling did not differ between treatments $(\mathrm{P}>0.05)$. The differences were observed after storage with their rise through the use of conditioners (Table 4). According to Reis et al. (1995), nitrogen retention can vary depending on the moisture content of stored forage. Avila et al. (2009) reported about the immobilization of nitrogen by mycelial fungi growing in silages of Mombaça grass, and according to Guim et al. (2002), this immobilization of nitrogen would be held by the hyphas of filamentous fungi.

The studies on quantification and assessment of genera and species of fungi in hay have been carried out in ammoniated hay or straw with urea or ammonia (Reis et al., 1991, Reis et al., 1997, Almeida et al., 2006). For the total population of fungus, there was a significant interaction of factors $(p<0.05)$. At the unfolding of the evaluation times collected for each drying method, we observed a higher population of fungi in the hay after storage, whereas, when comparing the methods of drying, there was significant difference between them only after storage, with the occurrence of lower fungi population in the hay submitted to two conditionings (Table 5). This result is due to higher DM of the hay resulting from this drying method, which, by causing injury to stems, favored the acceleration of dehydration rate in the final stage of dehydration, when the moisture removal is slower, because it happens through the cuticle (Moser, 1995). The use of this technique provided the hay with a higher content of $\mathrm{DM}$ in the baling, limiting the development of fungus; however, this hay showed, after storage, lower levels of CP. Nascimento et al. (2000), when studying the development of fungi on alfalfa hay under different methods of dehydration, saw significant occurrence of fungi in the material that underwent slower dehydration and lower incidence of solar radiation. Also, according to Gregory (1963), during the drying on field there is the occurrence of a highly diverse population of microorganisms, some living in the air, plants and soil; and this diversity of present propagules suggests that different types of micro flora can develop later on, according to the conditions that will prevail in bales at any time.

Table 5 - Means transformed in log x of fungi (CFU/g x10²) in Tifton 85 hay subjected to different methods of dehydration before the cutting, at the time of baling and 30 days after storage

\begin{tabular}{lllll}
\hline Drying methods & \multicolumn{1}{c}{ Cut } & Baling & Storage & Means \\
\hline 1 cond. +1 turn-over & $1.43\left(27.5 \times 10^{2}\right) \mathrm{aB}$ & $1.43\left(19.33 \times 10^{2}\right) \mathrm{aB}$ & $2.39\left(258.66 \times 10^{2}\right) \mathrm{aA}$ & $1.75\left(35.05 \times 10^{2}\right) \mathrm{a}$ \\
2 cond. +1 turn-over & $1.40\left(27.83 \times 10^{2}\right) \mathrm{aB}$ & $1.27\left(29.16 \times 10^{2}\right) \mathrm{aB}$ & $1.63\left(58.33 \times 10^{2}\right) \mathrm{bA}$ & $1.43\left(105.22 \times 10^{2}\right) \mathrm{b}$ \\
1 turn-over & $1.31\left(21.50 \times 10^{2}\right) \mathrm{aB}$ & $1.53\left(36.83 \times 10^{2}\right) \mathrm{aB}$ & $2.54\left(397.00 \times 10^{2}\right) \mathrm{aA}$ & $1.80\left(151.77 \times 10^{2}\right) \mathrm{a}$ \\
2 turn-overs & $1.34\left(23.00 \times 10^{2}\right) \mathrm{aB}$ & $1.48\left(32.00 \times 10^{2}\right) \mathrm{aB}$ & $2.50\left(342.66 \times 10^{2}\right) \mathrm{aA}$ & $1.77\left(132.55 \times 10^{2}\right) \mathrm{a}$ \\
Means & $1.37\left(24.95 \times 10^{2}\right) \mathrm{B}$ & $1.43\left(29.33 \times 10^{2}\right) \mathrm{B}$ & $2.27\left(264.17 \times 10^{2}\right) \mathrm{A}$ & \\
CV\% & & & &
\end{tabular}

Values followed by the same capital letters on the row and lowercase letters on the column do not differ by Tukey test at $5 \%$. 
The genera of fungi observed were Aspergillus, Penicillium, Fusarium, Bipolaris, Cladosporium and Rhizopus (Figure 3). At cutting and baling, fungi of the genera Fusarium, Cladosporium and Bipolaris prevailed; and after storage, besides the increase in the total number of colonies, there was an increase in the number of colonies of Aspergillus and reduction in the number of colonies of fungi found in the early stages (cutting and baling). Reis et al. (1997) observed in Cynodon dactylon hay increase in the fungi gender Aspergillus with increased moisture in the hay. Storage fungi such as Aspergillus can serve as a biological indicator of storage conditions, and its quantification in conserved forages is fundamental, once it represents a potent producer of mycotoxins (Moser, 1995), occurring more often in hot and humid environments.
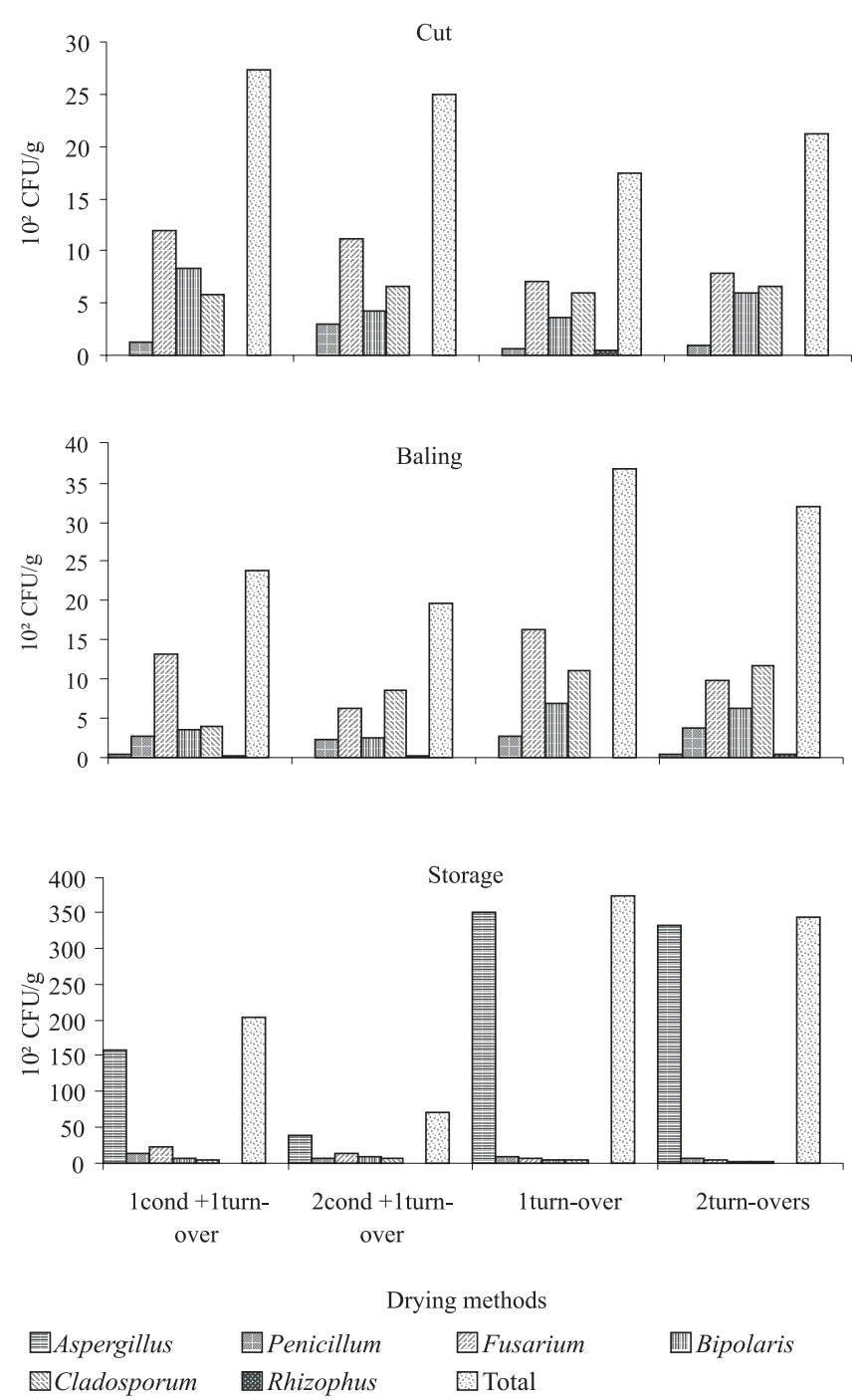

Figure 3 - Occurrence of fungus in Tifton 85 hay produced under different methods of dehydration at the time of cutting, baling and 30 days after storage (original data).
The population of Cladosporium found in hay varied as for storage times, with lower population after storage (Figure 3). The results are consistent with Nascimento et al. (2000) because, according to the author, this represents a genus of saprophytic fungi, which tends to disappear over the course of the storage period.

\section{Conclusions}

Tifton 85 dehydrated with the use of conditioners presents higher drying rate and lower incidence of fungi after 30 days of storage, in spite of the lower crude protein.

Further detailed research is necessary in order to quantify and qualify the effects of the use of conditioners on the time for the forage baling and on the nutritional composition of the hay produced.

\section{References}

AGRICULTURAL AND FOOD RESEARCH COUNCIL - AFRC. Energy and protein requirements of ruminants. Farnham Royal: CAB International, 1995. 59p.

AGUIAR, E.M.; COSTA LIMA, G.F.; SANTOS, M.V.F. et al. Rendimento e composição químico-bromatológica de fenos triturados de gramíneas tropicais. Revista Brasileira de Zootecnia, v.35, n.6, p.2226-2233, 2006.

ALMEIDA, J.C.C.; PÁDUA, F.R.; NEPUMUCENO, D.D. et al. Ocorrência de fungos no feno de grama-batatais (Paspalum notatum) em função da dose de uréia, período de tratamento e teor de umidade. Livestock Research for Rural Development, v.18, n.6, p.1-6, 2006. Available at: <http://www.lrrd.org/lrrd18/ 6/carv18080.htm>. Sept. 3, 2008.

ALVIM, M.J.; XAVIER, D.F.; VERNEQUE, R.S. et al. Resposta do tifton 85 a doses de nitrogênio e intervalos de cortes. Pesquisa Agropecuária Brasileira, v.34, n.12, p.2345-2352, 1999.

ASSOCIATION OF OFFICIAL ANALYTICAL CHEMISTS - AOAC. Official methods of analysis. 15.ed. Virginia: Arlington, 1990. 1117p.

ÁVILA, C.L.S.; PINTO, J.C.; FIGUEIREDO, H.C.P. et al. Estabilidade aeróbia de silagens de capim-mombaça tratadas com Lactobacillus buchneri. Revista Brasileira de Zootecnia, v.38, n.5, p.779-787, 2009.

BARNETT, H.L.; HUNTER, B.B. Illustrated genera of imperfect fungi. New York: Macmillan Publishing Company, 1987. 218p.

CARMICHAEL, J.W.; KENDRICK, W.B.; CONNERS, I.L. et al. Genera of Hyphomycetes. Manitoba: Hignell Printing, 1980. 386p.

COLLINS, C.A. Hay preservation effects on yield and quality. In: Post-harvest physiology and preservation of forages. MOORE, K.J.; KRAL, D.M.; VINEY, M.K. (Eds). Madison, Wisconsin: American Society of Agronomy, 1995. p.67-90.

DETMANN, E.; ZERVOUDAKIS, J.T.; CABRAL, L.S. et al. Validação de equações preditivas do potencial de degradação da fibra em detergente neutro em gramíneas tropicais. Revista Brasileira de Zootecnia, v.33, n.6, p.1866-1875, 2004.

DOMINGUES, J.L. Uso de volumosos conservados na alimentação de eqüinos. Revista Brasileira de Zootecnia, v.38, supl., p.259-269, 2009.

EMPRESA BRASILEIRA DE PESQUISA AGROPECUÁRIA EMBRAPA. Centro Nacional de Pesquisa de Solos. Sistema brasileiro de classificação de solos. 2.ed. Rio de Janeiro, 2006. 306p. 
EMPRESA BRASILEIRA DE PESQUISA AGROPECUÁRIA EMBRAPA, Sistema Brasileiro de Classificação de Solos. Brasília, 2006. 412p.

FERNANDEZ, M.R. Manual para laboratório de fitopatologia. Passo Fundo: EMBRAPA-CNPT, 1993. 128p.

GOBBI, K.F.; GARCIA, R.; PEREIRA, O.G.; BERNARDINO, F.S. et al. Composição química e digestibilidade in vitro do feno de Brachiaria decumbens Stapf. tratado com uréia. Revista Brasileira Zootecnia, v.34, n.3, p.720-725, 2005.

GREGORY, P.H. Microbial and biochemical changes during the moulding of hay. Journal of Genetic Microbiology, v.33, n.1, p.147-174, 1963.

GUARRO, J.; GENÉ, J.; STCHIGEL, A.M. Developments in fungal taxonomy. Clinical Microbiology Reviews, v.12, n.3, p.454-500, 1999.

GUIM, A.; ANDRADE, P.; ITURRINO-SCHOCKEN, R.P. et al. Estabilidade aeróbica de silagens de capim-elefante (Pennisetum purpureum, Schum) emurchecido e tratado com inoculante microbiano. Revista Brasileira de Zootecnia, v.31, n.6, p.2176-2185, 2002.

HENRIQUES, L.T.; VASQUES, H.M.; PEREIRA, O. Frações dos compostos nitrogenados associados à parede celular em forragens tropicais. Arquivos Brasileiros de Medicina Veterinária e Zootecnia, v.59, n.1, p.258-263, 2007.

HLODVERSSON, R., KASPERSSON, A. Nutrient losses during deterioration of hay in relation to changes in biochemical composition and microbial growth. Animal Feed Science Technology, v.15, n.2, p.149-165, 1986.

INSTITUTO AGRONÔMICO DO PARANÁ - IAPAR [2006]. Cartas climáticas do Paraná. Available at: <http://200.201.27.14/ Site/Sma/Cartas_Climaticas/Classificação__Climaticas.htm>. Accessed on: Sept. 3, 2008.

JOBIM, C.C.; NUSSIO, L.G.; REIS, R.A.; SCHMIDT, P. Avanços metodológicos na avaliação da qualidade da forragem conservada. Revista Brasileira de Zootecnia, v.36, supl. p.101-119, 2007.

JUNG, H.G.; ENGELS, F.M. Alfalfa stem tissues: cell, wall deposition, composition and degradability. Crop Science, v.24, n.2, p.524-534, 2002

LACERDA, R.S.; GOMIDE, C.A.; FUKUSHIMA, R.S.; HERLING, V.R. Lignin concentration in oat (Avena byzantina L.) aerial part as mensured by four analytical methods. Brazilian Journal Veterinary Research: Animal Science, v.43, n.3, p.400-407, 2006.

LADEIRA, M.M.; RODRIGUEZ, N.M.; BORGES, I. et al. Avaliação do feno de Arachis pintoi utilizando o ensaio de digestibilidade in vivo. Revista Brasileira de Zootecnia, v.31, n.6, p.2350-2356, 2002.

MATOS, L.L. Utilização de fibra pelos ruminantes. In: MINI SIMPÓSIODO COLÉGIO BRASILEIRO DE NURTIÇÃO ANIMAL, 2., 1989, Campinas. Anais... Campinas: CBNA, 1989. p.8-10.

MENEZES, M.; SILVA-HANLIN, D.M.W. Guia prático para fungos fitopatogênicos. Recife: UFRPE, 1997. 106p.

MOREIRA, A.L.; REIS, R.A. Técnica da sobressemeadura de forrageiras de inverno sobre o capim-tifton 85. Boletim Indústria Animal, v.64, n.3, p.197-206, 2007.

MOSER, L.E. Post-harvest physiological changes in forage plants. In: MOORE, K.J.; KRAL, D.M.; VINEY, M.K. (Eds). Post-harvest physiology and preservation of forages. Madison, Wisconsin: American Society of Agronomy, 1995. p.1-19.

MUCK, R.E.; SHINNERS, K.J. Conserved forages (silage and hay): Progress and Priorities. In: INTERNATIONAL GRASSLAND CONGRESS, 29., 2001, São Pedro. Proceedings... Piracicaba: Brazilian Society of Animal Husbandry, 2001. p.753-763.
NASCIMENTO, J.M.; COSTA, C.; SILVEIRA, A.C. Influência do método de fenação e tempo de armazenamento sobre a composição bromatológica e ocorrência de fungos no feno de alfafa (Medicago sativa, L. cv. Flórida 77). Revista Brasileira de Zootecnia, v.29 n.3, p.669-677, 2000.

OLIVEIRA, M.A.; PEREIRA, O.G.; HUAMAN, C.A.M. et al. Características morfogênicas e estruturais do capim bermuda “Tifton 85" (Cynodon spp.) em diferentes idades de rebrota. Revista Brasileira de Zootecnia, v.29, n.6, p.1939-1948, 2000 .

PUPO, N.I.H. Manual de pastagens e forrageiras: formação, conservação, utilização. Campinas: Instituto Campineiro de Ensino Agrícola, 1995. 343p.

REIS, R.A.; BERCHIELLI, T.T.; ANDRADE, P. et al. Valor nutritivo do feno de capim coast-cross (Cynodon dactylon L. Pers) submetido à amonização. Ars Veterinária, v.19, n.2, p.143-149, 2003.

REIS, R.A.; GARCIA, R.; QUEIROZ, A.C. Efeitos da amonização sobre a qualidade dos fenos de gramíneas tropicais. Pesquisa Agropecuária Brasileira, v.26, n.8, p.1183-1191, 1991.

REIS, R.A.; PANIZZI, R.C.; ROSA, B. Efeito da amonização sobre a ocorrência de fungos, composição química e digestibilidade in vitro de fenos de grama seda (Cynodon dactylon (L.) Pers). Revista Brasileira de Zootecnia, v.26, n.3, p.454-460, 1997.

REIS, R.A.; RODRIGUES L.R.A.; PEDROSO, P. Avaliação de fontes de amônia para o tratamento de volumosos de baixa qualidade. Revista Brasileira de Zootecnia, v.24, n.4, p.487-493, 1995.

REIS, R.A.; SOLLENBERGER, L.E.; URBANO, D. Impacto $f$ overseeding cool-season annual forages on spring regrowth of Tifton 85 bermudagrass. In: INTERNATIONAL GRASSLAND CONGRESS, 19., 2001, São Pedro. Proceedings... São Pedro: Brazilian Society of Animal Husbandry, 2001. p.295-297.

RIBEIRO, K.G.; PEREIRA, O.G.; VALADARES FILHO, S.C. et al. Caracterização das frações que constituem as proteínas e os carboidratos, e respectivas taxas de digestão, do feno de capim tifton-85 de diferentes idades de rebrota. Revista Brasileira de Zootecnia, v.30, n.2, p.589-595, 2001

ROCHA, G.P.; EVANGELISTA, A.R.; LIMA, J.A. Nitrogênio na produção de matéria seca, teor e rendimento de proteína bruta de gramíneas tropicais. Pasturas Tropicales, v.22, n.1, p.4-8, 2000.

ROTZ, C.A. Field curing of forage. In: MOORE, K.J.; KRAL, D.M.; VINEY, M.K. (Eds). Post-harvest physiology and preservation of forages. Madison: American Society of Agronomy, 1995. p.39-66.

UNIVERSIDADE FEDERAL DE VIÇOSA - UFV. Sistema para análises estatísticas e genética - SAEG. versão 7.0. Viçosa, MG, 1997. (CD-ROM).

SAMSON, R.A.; HOEKSTRA, E.S.; FRISVAD, J.C. et al. Introduction to food-borne fungi. Baarn: CBS, 1995. 322p.

SCHEFFER-BASSO, S.M.; ELLWANGER, M.F.; SCHERER, C.V. et al. Resposta de pastagens perenes à adubação com chorum suíno: cultivar Tifton 85. Revista Brasileira Zootecnia, v.37, n.11, p.1940-1946, 2008.

SILVA, D.J.; QUEIROZ, A.C. Análise de alimentos: métodos químicos e biológicos. Viçosa, MG: UFV, 2006. 235p.

VAN SOEST, P.J. Nutritional ecology of the ruminant. Ithaca: Constock Publishing Associates, 1994. 476p.

VAN SOEST, P.J. ROBERTSON, J.B., LEWIS, B.A. Methods for dietary fiber, neutral detergent fiber and non starch polysaccharides in relation to animal nutrition. Journal of Dairy Science, v.74, p.3583-3597, 1991 